\title{
Akhaimenid Döneminde Büyük Phrygia ve Bölgedeki Yol Ağları
}

\section{Greater Phrygia and the Road Systems in the Region During the Achaemenid Period}

\author{
Muzaffer DURAN*
}

\begin{abstract}
$\ddot{O z}$
Persler Anadolu'ya hakim olduktan sonra Anadolu topraklarını idari yönetim bölgelerine (satraplık) ayırmıştı. Bu bölgelerden biri de Phrygia'dır. Ancak Pers döneminde Hellespontos Phrygia's1 (Daskyleion) ve Büyük Phrygia adı altında iki ayrı Phrygia bulunmaktaydı. Kıyı Phrygia olarak da bilinen Hellespontos Phrygia'sı üzerine yapılan bir çok çalışma mevcuttur. Ancak doğrudan Büyük Phrygia adı altında yapılan çalışmalar oldukça sınırlıdır. Bu çalışmamızın temel amacı Pers döneminde Büyük Phrygia'da vuku bulan meseleler; bölgede söz sahibi olan yöneticiler; bölgede bulunan şehirler ve yol ağlarına dair açıklamalarda bulunmaktır. Bu hususta bir çok sorun bulunmaktadır. Sorunların kaynağı antik kaynakların yeterince bilgi vermemesidir. Çalışmamızın neticesinde Büyük Phrygia hakkında MÖ. 4. yüzyıldan itibaren kaynakların daha fazla bilgi vermeye başladığını; bölgenin özellikle II. Artakserkses dönemi ile birlikte sorunlara gebe kaldığını; aynı yüzyıldan itibaren bölgede çıkan ayaklanmalar ve dış müdahaleler konusunda Anadolu'nun batısındaki diğer satraplıklara nazaran olayların çok fazla içinde yer almadığını; Kral Yolu güzergahında bulunmasından dolayı bölgenin stratejik öneme haiz olduğunu; özellikle Kelainai kentinin anahtar şehir konumunda bulunduğunu söyleyebiliriz.
\end{abstract}

Anahar Kelimeler: Persler (Akhaimenidler), Büyük Phrygia, Kral Yolu, Kelainai.

\section{Abstract}

When the Persians dominated Anatolia, they separated Anatolian territories into administrative zones called satrapy. One of these satrapy zones is Phrygia. However, there were two distinct Phrygia under the names of Phrygia of Hellespontos (Daskyleion) and the Greater Phrygia during the Persian era. There are many studies on Phrygia of Hellespontos which is also known as Coastal Phrygia. But studies that were done directly under the name of Greater Phrygia are quite limited. The main goal of this study is to make explainations on the matters happened in the Greater Phrygia, rulers who had powers in the region, the cities and road systems during the Persian era. There are several problems in this respect. The crux of the problems is that antique sources couldn't provide information sufficiently. As a result of our study we can say that the sources give more information about Greater Phrygia from the 4th century BC onwards, the region started to have problems especially as from Artaxerxes era, it did not take part in the events of the same century with respect to the uprisings and foreign interventions in the region when compared to the other satrapys locating in the Western Anatolia, the region has strategic importance due to its location in Royal Road and the city of Celaenae is a key city.

Key Words: Persians (Achaemenids), Greater Phrygia, The Royal Road, Celaenae.

\section{Giriş}

Tunç çağının sonunda gerçekleşen ve dönemin dünya nizamını değiştiren birtakım meseleler neticesinde Hitit, Mitanni, Babil gibi güçlü krallıklar tarih sahnesinden çekilmişti. ${ }^{1}$ Ardından yaşanan birkaç yüz yıllık karanlık devirden sonra Anadolu yeni siyasi figürlerle karşılaştı. Bu figürlerden biri de Phrygialılardır. Anadolu'da güçlü bir krallık kuran Phrygialılar MÖ. 7. yüzyılda Kimmer baskınına dayanamadı ve yıkıldı. Ardından Anadolu'da (Halys'e kadar) Lydia hâkimiyet dönemi başladı (Hdt. I.6, 15-16). Her ne kadar Phrygia Krallığı tarih sahnesinden silinse de halkı ve isimleri yüzyıllarca yaşamaya devam etti.

Herodotos'a göre (Batı Anadolu'da Lydia hâkimiyeti döneminde, Halys'in (Kızılırmak) batı yakasında kalan halklardan Kilikia ve Lykia hariç bütün hepsi Lydia Kralı Kroisos'un egemenliğindeydi. Bu halklar Phrygialılar, Mysialılar, Mariandynler, Khalybler, Paphlagonialılar, Traklar, Thynler, Bithynialılar, Karialılar, Ionialılar, Dorlar, Aiolialılar ve Pamphylialılardır. Lydialıların en büyük rakibi ise İran merkezli büyük bir devlet kuran

\footnotetext{
* Dr.Öğr. Üyesi, Süleyman Demirel Üniversitesi, Tarih Bölümü, Eskiçağ ABD, muzafferduran@ @du.edu.tr.

${ }^{1} \mathrm{Bu}$ mesele son zamanlara kadar "Deniz Kavimleri Göçleri” ile açıklanmaktaydı. Ancak yakın zamanlarda yapılan araştırmalarla bu durum farklı nedenlere bağlanarak tartışılmaktadır. Tartışmalar için bkz. Cline, 2018; Drews, 2012.
} 
Medlerdi. İki ülke arasındaki sınırı Halys oluşturmaktaydı. Nehrin batısındaysa Phryg toplulukları yaşamaktaydı (Hdt. I.28, 72). Pers kralı Büyük Kyros, Med egemenliğine son verince (Hdt. I. 73) Anadolu ve dolayısıyla Phrygia bölgesi Pers egemenliğine dahil oldu. Ancak Pers döneminde Anadolu'da iki Phrygia bölgesiyle karşılaşmaktayız. Bunlar Kuzeybatı Anadolu'daki Hellespontos Phrygia'sı ile Orta-İçbatı Anadolu'yu içeren Büyük Phrygia bölgeleridir. Genç Kyros'un MÖ. 407'lerde karanos olarak Anadolu'ya gönderilmesine kadar iki Phryg bölgesinin de Hellespontos Phrygia'sının idare merkezi olan Daskyleion yönetiminde olduğu düşünülmektedir. Genç Kyros, Sardeis'e geldiğinde Büyük Phrygia'nın bir kısmı Kappadokia ve Lydia ile birleştirildi, diğer kısmı Daskyleion'un hakimiyetinde kalmaya devam etti. Böylece Phrygialılar iki farklı satraplığa bağlanmış oldu (Maffre, 2017, s. 52-61).

\section{Büyük Phrygia'nın Oluşumu, Sınırları ve Siyasi Meseleler}

Perslerin kurucu kralı Büyük Kyros, MÖ. 547/6'da Lydialı Kroisos'u mağlup etmiş ve Anadolu Pers hakimiyetine girmişti (Hdt. I. 75-84; Sevin, 1982, s. 268). Herodotos, Kyros'un Anadolu'da Sardeis (Lydia) ve Daskyleion (Hellespontos Phrygia's1) satraplik merkezleri oluşturduğunu söylemektedir (Hdt. I.20). Ksenophon da Anadolu'da Pers buyruğuna giren bölgeleri sayarken Kappadokia ve Lydia ile birlikte iki Phrygia krallığından bahsetmektedir (Ksen. Kyr. I.1). Ayrica Kyros'un Babil'i ele geçirmesinden sonra bölgelerin yönetimi için satraplar tayin ettiğini ifade etmektedir. Bu doğrultuda Hellespontos Phrygia'sına Pharnakes, Büyük Phrygia'ya Artakamas'ın atandığını belirtir (Ksen. Kyr. VIII.6.7-8). Ksenophon Kyroupedia'da her ne kadar Büyük Kyros döneminde Büyük Phrygia satrapından bahsetse de satraplık hakkında daha fazla malumat vermemektedir. Herodotos'da da I. Darius'un satraplık listesinde üçüncü satraplık dahilinde Phrygia anılsa da burası Darius yazılarında tyaiy drayahya olarak geçen Hellespontos, yani kıyı Phrygia'sıdır (Hdt. III. 90; DB. col. 6-7; DPe § 2. 13-14; DSe § 3. 28; Kaya, 2018, s. 168; Sarıkaya, 2015, s. 40).

Büyük Phrygia'nın bir satraplık olup olmadığı konusu tartışmalıdır. Fakat en azından Ksenophon'un yukarıdaki ifadeleri buranın bir satraplık olduğunu yansıtmaktadır (Hornblower, 1994, s.78 dn. 124). Büyük Phrygia hakkında pek fazla malumat olmasa da kaynaklar buranın da Hellespontos Phrygia's1, Lydia ve Karia satraplıklarıyla aynı asil yerleşim düzenine sahip olduğunu göstermektedir. Gerçekten de Phrygia üzerindeki İran etkisi oldukça etkili görünmektedir (Sekunda, 2011, s. 53). Buna rağmen Büyük Phrygia'nın satraplık olarak ne zaman Pers yönetim sistemine dahil edildiği belli değildir. Nitekim Pers krallarının gerekli gördükleri zaman satraplıkları tek bir bölge altında birleştirdiğini ya da küçük satraplıkları yönetim sisteminden çıkardığını bilmekteyiz (Schmitt, 1986, s. 420; Casabonne, 2007, s. 26; Herzfeld, 1968, s. 311-312; örnek uygulamalar için bkz. Jacobs, 2011: http://www.iranicaonline.org/articles/achaemenid-satrapies). P. Briant Büyük Phrygia'nın satraplık olarak sisteme dahil edilmesinin 4. yüzyılda olduğunu düşünmektedir (Briant, 2002, s. 706; Kaya, 2018, s. 165). ${ }^{2}$

Antik kaynaklar Büyük Phrygia'nın sınırları hakkında bütün yönleriyle bilgi vermese de bazı noktalarda net bilgiler sunmaktadır. Ksenophon'un ifadelerine göre bölgenin sınırları Mysia ve Lydia ile sınırdaştır. Doğuya doğru son şehri Ikonion'dur (Ksen. anab. I.2.10-19;

\footnotetext{
${ }^{2}$ Arrianos (anab. I.24.5) Büyük İskender'in Granikos Savaşı'ndan sonra Anadolu'nun güneyine doğru yöneldiği sırada Milyan bölgesinin Phrygia'ya ait olduğunu fakat Pers kralının (III. Darius) emriyle burasının Lykia'nın bir parçası yapıldığını söylemektedir. I. Darius döneminde de Lykia ve Milyan birinci eyaletin bir parçasıydı (Hdt. III.90). Ancak sürekli yapılan düzenlemelerle yeni satraplık bölgeleri oluşturuldu. Artık bir bölgenin eskiden bağlı olduğu haraç bölgesiyle bağlantılı olması gerekmiyordu. Bir ethna yeni oluşturulan bir satraplığa geçirilebilirdi. P. Birant burada söz konusu durumdan yola çıkarak Büyük Phrygia'nın oluşturulmasının bundan önceki yakın bir zamana tarihlendirilebileceğini, Pers krallarının bölgesel sorunlara çözüm bulmak amacıyla bu tarz uygulamalar yaptığını ifade etmektedir.
} 
ayrıca bkz. Hdt. VII.30). Mysia yönündeki son şehir ise Keramon Agora'dır (Ksen. anab. I.2.10). Jacobs, Büyük Phrygia satraplığının güneyde Lykonia, Pisidia ve Pamphylia'yı da kapsayarak denize ulaştığını ifade etmektedir. Jacobs bu düşüncesini İskender zamanındaki atamalardan yola çıkılarak ileri sürmektedir. Zira Büyük İskender, Pamphylia ve Büyük Phrygia'yı yeniden bir arada yönetmişti. Buna göre Büyük Phrygia'nın alanı doğuda Kelenderis ve Korakesium ${ }^{3}$ arasındaki bölgeden batıdaki Phaselis'e kadar uzanmıştır. Bu sınırdan iç bölgelere doğru sınırlar belli olmasa da Kolossai'nin (Honaz) Büyük Phrygia şehri olduğu kesindir. Satraplığın kuzey sınırı Hellespontos Phrygia'sına ait olan Gordion'a dayanmaktaydı. Doğuda ise Halys daha güneydeki Toros Dağları'nın sınırını işaretlemekteydi (Jacobs, 2011: http://www.iranicaonline.org/articles/achaemenid-satrapies). Sekunda ise Phrygia'nın güneydoğu sınır bölgelerinin Lydialı Paktyes' ait olan ve Perslerce el konulan topraklardan oluştuğunu (Sekunda, 2011, s. 55), Kolossai şehrinin Büyük Phrygia topraklarının güneybatı sınırı olduğunu düşünmektedir. Anlaşılan odur ki Hellespontos Phrygia'sı Anadolu'da Hellespontos'un güney-doğusuna doğru uzanırken, Büyük Phrygia Anadolu'nun ortasındadır. Her iki bölge Lydia vasıtasıyla bir diğerinden ayrılmaktadır (Sekunda, 2011, s. 48).

Plutarkhos'un ifadeleri (Sekunda'ya göre MÖ. 5. yüzyılın ortalarında) Büyük Phrygia'daki bir satrapa atıfta bulunmaktadır. Ona göre satrap, Epiksyes adıyla (Yukarı Phrygia satrap1) anılmaktaydı. Sekunda bu dönemde Büyük Phrygia Epiksiyes'inin Arsames olabileceğini düşünmektedir (Plut. Them. 30.1; Sekunda, 1991, s. 112). Arsames ile ilgili bilgileri Polyainus'da bulmaktayız. Ona göre Arsames, Barka şehrini kuşatmıştı. Barka halkı ona kuşatmayı kaldırması için elçiler gönderdi. O da Pers kralına karşı olan Yunanlara karşı ittifak yapmaları halinde anlaşmayı kabul edeceğini bildirdi ve her iki taraf da bu konuda mütabık oldu. Ancak Arsames daha sonra bir hile ile şehri yağmaladı ve halkını kılıçtan geçirdi (Polyain. strat. VII.28.1). Polyainus bir başka pasajında ise Arsames'in krala isyan ettiğinden, Büyük Phrygia satraplığını kontrol altına alarak kralın generalleri ile savaşa giriştiğinden bahsedilmektedir. Bu sırada kendi süvari komutanının (hyparkhos) ihanet ederek düşmanıyla işbirliği yaptığı haberini aldığı, ancak daha sonra bu oyunu bozduğu anlatılmaktadır (Polyain. strat. VII.28. 2). Buradaki temel sorun Arsames'in yaşadığı dönemin belli olmamasıdır (Hornlower, 1994, s. 78). Sekunda bu dönemi MÖ. 450'lerdeki Mısır ve muhtemelen Kyrenaika'nın Pers yönetiminden geçici olarak kurtulduğu dönemle bağdaştırmaktadır (Sekunda, 2011, s. 54). Burada bahsi geçen süvariler muhtemelen Büyük Phrygia satraplığındaki Persli toprak sahipleriydi (Sekunda, 2011, s. 54; Sekunda, 1991, s. 112). İsyanın bastırılmasının ardından Büyük Phrygia'ya yeni bir satrap atandığ varsayılmaktadır. Araştırmacılar -aşağıda bahsedeceğimiz II. Artakserkses'in khiliarkhos'u olan ve Anadolu'ya gönderilen Tithraustes'i dikkate alarak- Eurymedon Savaşı'nda (MÖ. 467/6) Kserkses'in kraliyet donanma komutanı ve aynı zamanda gayrı meşru oğlu olan Tithraustes'in satraplığ 1 devraldığını ve bundan sonra onun ailesine bu görevin miras kaldığını düşünmektedir (Diod. 11.60.5; Plut. Kim. 12.4; Sekunda, 2011, s. 54; Sekunda, 1991, s. 112; Olmstead, 1948, s. 268; Kuhrt, 2007, s. 292). ${ }^{4}$

MÖ. 5. yüzyılın sonları-4. yüzyılın başlarına gelindiğinde Büyük Phrygia ile ilgili bilgiler artmaktadır. Nitekim MÖ. 5. yüzyılın sonlarında II. Darius'un ölümünün ardından kral olan oğlu II. Artakserkses (MÖ. 405-359) ile diğer oğlu Genç Kyros arasında çıkan taht kavgası sırasında ve sonrasında Anadolu'da yaşanan meseleler Büyük Phrygia bölgesine dair çıkarımlarda bulunmamıza yardım etmektedir. Yeni kral II. Artakserkses, kardeşi Genç Kyros'u annesi Parysatis'in etkisiyle karanos ünvanıyla Küçük Asya'ya gönderdiğinde, ona

\footnotetext{
${ }^{3}$ Kelenderis=Mersin Aydıncık; Korakesium=Alanya. Bkz. Umar, 1993, s. 71, 368.

${ }^{4}$ Sekunda (2011: 55), Dinar (Kelainai) yakınlarındaki Tatarlı'da bulunan mezarın (Sümerer, 2010, s. 120-185) söz konusu Tithraustes'e ait olduğunu düşünmektedir.
} 
Lydia satraplığg ile beraber Büyük Phrygia ve Kappadokia'nın yönetimini de vermişti (Ksen. Hell. I.4.3 anab. I. 1-4; Plut. Artaks. II.1-3; Sarıkaya, 2015, s. 106). Genç Kyros, ağabeyi olan Büyük Kral II. Artakserkses'i tahttan indirmek için hazırlıklara başladı (Ksen. anab. I. 1. 210). Kyros'tan önce Lydia satrapı olan Tissaphernes, II. Darius'un emriyle görevi Kyros'a devretmişti (Sarıkaya, 2015, s. 106). Tissaphernes, Kyros'un isyan edeceğini öğrenir öğrenmez haberi kral II. Artakserkses'e ulaştırdı (Ksen. anab. I. 204; Sarıkaya, 2015, s. 117). Babil civarındaki Kunaksa'da yapılan iktidar savaşında Genç Kyros öldürüldü (Ksen. anab. I.8.27-29; Ctes. F16. Photius 43b3-44a19 (§64-67); Plut. Artaks. XI-XII) ve Anadolu'nun batısında deniz kıyısında Genç Kyros'un satraplık yaptığı bölgelere satrap olarak tekrar Tissaphernes atand1 (Ksen. Hell. III.2.13; Diod. 14.26.4).

II. Artakserkses Genç Kyros meselesi ile uğraşırken Yunanistan'da da iç savaş yaşanmaktaydı ve uzun yıllar süren Atina-Sparta Savaşı MÖ. 404'lerde sona ermişti (Thuk. ilgili yerler). Anlaşılan Yunanlar ve Persler iç meselelerini halletmiş gibi görünmektedir. Ancak birkaç yıl sonra Küçük Asya'nın batısında işler Perslerin istediği gibi gitmedi. Antik kaynaklar bu dönemde Anadolu'nun batısında yaşanan olayları detaylıca sunmaktadır. Önce MÖ. 399'da Lakedaimonlu Thibron, Anadolu kıyılarına ayak bastı (Ksen. Hell. III.1.4). Genç Kyros'un yanında savaşmış olan On Binler de ona katıldı (Ksen. Hell. III.1.6, anab. VII.8.24). Thibron daha sonra Sparta'ya geri çağrıldı ve yerine Derkylidas geçti, Sardeis satrap1 Tissaphernes ile Daskyleion satrapı Pharnabazus'un arasını açmak için uğraşa başladı (Ksen. Hell. III.1.8-9). Batı Anadolu'da bazı yerleri ele geçirse de Magnesia'da Perslerle bir anlaşma tatbik etti (Ksen. Hell. III.2.18-20). MÖ. 398/97'de bu kez Agesilaos, Küçük Asya'da kendini gösterdi. Anadolu'da Perslere darbeler vurmaya başlayan Agesilaos, MÖ. 395'te Tissaphernes'i ağır bir yenilgiye uğrattı (Ksen. Hell. III.4.21-25, Ages. I.28-34; Corn. Nep. Ages. XVII.3.4-6; Plut. Ages. X.1-4, Artaks. XX. 2-3; Briant, 2002, s. 637). Tissaphernes'in bu mağlubiyeti onun ölüm fermanını hazırlayan en önemli sebep oldu (Sarıkaya, 2015a, s. 204). Nitekim mağlubiyetten sonra Sardeis’teki Persler tarafından suçlanan Tissaphernes ölüm cezasına çarptırıldı. (Occhipinti, 2016, s. 50).

Agesilaos Tissaphernes zaferinin ardından Perslerle bir anlaşma yaparak ordusuyla Daskyleion'da konaklamayı kabul etmişti (Ksen. Hell. III.4.25-26; Hell. Oxy. 21.5-22.3; Plut. Ages. 10.4-5; Ksen. Ages. IV.6; Diod. XIV.80.8; Corn. Nep. Ages. 2). Ancak daha sonra anlaşmayı bozarak Mysia bölgesine girdi ve bölgeyi talan etti. Ardından Leonton Kephalai ve Gordion şehirlerini yağmalamaya çalıştı. Fakat başarısız oldu. Zira Phrygia'dan sorumlu Pers soylusu Rhathanes'in ordusu güçlü bir direniş gösterdi. Agesilaos bu yenilginin ardından Pamphylia'ya, oradan da tekrar Batı Anadolu'ya ve son olarak Sparta'ya geri dönmek zorunda kaldı (Ksen. Hell. IV.1; Plut. Ages. XI.1; Hell. Oxy. 21.5-6; Sarıkaya, 2015, s. 298299). Leonton Kephalai'ye de saldıran Agesilaos bir başarı elde edemeden Gordion'a yönelmesi Leonton Kephalai'nin de tahkimli olduğunu düşündürmektedir (Sekunda, 1991, s. 130). Burada Rhathines'e de değinmek gerekir. Kaynaklarda hyparkhos olarak anılan Rhathanes'in Gordion' da yerleşik olduğunu düşünen Sekunda onun satrap değil Pers kralının bir subay1 olduğunu söylemektedir (Sekunda, 1991, s. 138). Ona göre Rhathines, bölgedeki üç büyük ailenin ${ }^{5}$ dışında sayılabilecek soylu bir kişidir. Büyük Kral tarafından bölgedeki meselelere yarımcı olmak için gönderildiği düşünülen Rhathanes'in tımar sahibi olmadığı, Pharnabazos'un süvari komutanı olduğu ileri sürülmektedir. Agesilaos'a karşı Gordion'u altı gün boyunca başarıyla savunan bu Pers soylusu Hellespontos Phrygia'sı satraplığının doğu uçlarını ya da Büyük Phrygia'yı da içine alan Gordion'un doğusunu kontrolü altında tuttuğu düşünülmektedir (Sekunda, 1988, s. 181; Hell. Oxy. 21). Burada yeri gelmişken bahsetmemiz gerekir ki Persler, satraplıkları bir çeşit tımar sistemi gibi bir organizasyonla idare etmekteydi.

\footnotetext{
${ }^{5}$ Hellespontos Phrygia'sındaki üç büyük aile Pharnakes, Ariobarzanes ve Spithridates hanedanlıklarıdır. Bkz. Körpe-Yavuz, 2012, s. 35-36; Sarıkaya, 2015.
} 
Bu hususta İran'dan gelen soylu aileler önemli bölgelere yerleştirilmekteydi. Bu büyük hanedanlıkların dışında statü olarak onların altında olan aileler de mevcuttu. Sekunda bu sistemi ortaçağ Avrupa'sındaki "düka"lık teşkilatına benzemektedir. Hatta bu ailelere bağlı "kont" ve "şövalye" gibi daha alt grupların olduğunu ileri sürmektedir (Sekunda, 1988, s. 178-180; Körpe-Yavuz, 2012, s. 35-36).

MÖ. 4. yüzyılında başlarında bütün bu olaylar ile bağlantılı olarak Büyük Phrygia ile bağdaştırabileceğimiz iki şahsiyet dikkat çekmektedir: Ariaios ve Tithraustes. Ariaios, eski Farsça bir ismin Yunanca formudur. Bu kişi Pers kralı II. Darius'un komutanlarından biriydi. Kaynaklarda hyparkhos olarak anılan Ariaios, Genç Kyros'un dostu ve arkadaşıydı. Taht mücadelesi sırasında Genç Kyros'un yanında yer aldı. Kunaksa'daki mücadelede Genç Kyros'un ordusunun sol kanadında, Asyalı birlikleri komuta etmişti (Ksen. anab. I.8.5, 9.31, 10.1, II.5.35, Oek. IV. 19; Plut. Artaks. 11.1; Diod. 14.22.5, 24.1 (Aridaeus); Ctes. F. 20. 11.1-2; Shahbazi, 1986, s. 405-406: http://www.iranicaonline.org/articles/ariaeus-militarycommander-in-the-army-of-cyrus-the-younger). Kyros'un hayatını kaybetmesi üzerine Spartalı Klearkhos liderliğindeki ücretli askerler, ondan Kyros'un davasını devralmasını ve tahta yürümesini istedi. Ancak Ariaios bu teklifi reddetti (Ksen. anab. II.1.1-6; II.2.1). Kral II. Artakserkses Genç Kyros'un yanında yer alan generallere af teklifinde bulundu. Ariaios ve pek çok komutan teklifi kabul etti ve büyük ödüller aldı. Ardından Lydia satrapı Tissaphernes ile iş tutarak Klearkhos'un öldürülmesine rol aldı (Ksen. anab. 2. 5.27-42; Oec. 4.19; Diod. 14.26.5-7; Shahbazi, 1986, s. 405-406: http://www.iranicaonline.org/articles/ariaeus-militarycommander-in-the-army-of-cyrus-the-younger). Ariaios'u daha sonra, MÖ. 395'teki Agesilaos mağlubiyetinden dolayı Tissaphernes'in öldürülmesi hadisesinde görmekteyiz (Sekunda, 2011, s. 56; Shahbazi, 1986, s. 405-406: http://www.iranicaonline.org/articles/ariaeus-military-commander-in-the-army-of-cyrus-theyounger). Olay şu şekilde gelişmişti: Büyük Kral hem Tithraustes'e hem Ariaios'a Tissaphernes'in yakalanması ve infaz edilmesini içeren bir mektup gönderdi. Ariaios, Tissaphernes'i Kolossai'ye davet etti. Burada onu yakalad1, kapalı bir araba içinde Tithraustes'e teslim etti. Tithraustes de Kelainai'de onun kafasını keserek idam etti (Polyain. strat. VII.16.1; Diod. 14. 80; Kuhrt, 2007, s. 373-374; Sekunda, 2011, s. 54). Bu olayın ardından Tithraustes Lydia'da düzeni tekrar sağlamak için girişimlerde bulundu. Konon'un isteği üzerine Tithraustes oradaki askerlere ödeme yapılması için iki yüz yirmi talent gümüş gönderdi. Tithraustes bölgede kısa bir süre bekledikten sonra iç bölgelere girdi, Ariaeus ve Pasiphernes'i bölgeden sorumlu generaller (strategoi) olarak atadı ve yanlarında yaklaşık yedi yüz talent bıraktı (Hell. Oxy. 19.1-3; Occhipinti, 2016, s. 109). Pers kralı böylece Tithraustes sayesinde Lydia'daki kontrolü sağlamış oldu. Yine kral onun aracılığıyla Agesilaos ile anlaşma yaptı ve onun Pharnabazos'un satraplığına (Daskyleion'a) gitmesini sağladı (Ksen. Hell. III.4.25-26; Plut. Ages. 10; Hell. Oxy. 19.3). Ariaios bu olaydan bir y1l bu kez Büyük Krala isyan etti (Ksen. Hell. 4.1.27; Shahbazi, 1986, s. 405-406: http://www.iranicaonline.org/articles/ariaeus-military-commander-in-the-army-of-cyrus-theyounger). Ariaios'un, Büyük Phrygia satraplığı yaptığı düşünülmektedir (Diod. 14.80.6-8

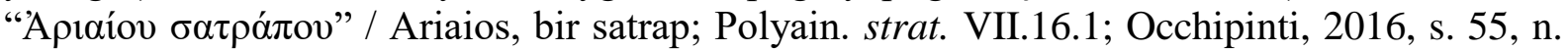
112; Olmstead, 1948, s. 384; Kuhrt ve Sancisi-Weerdenburg, 1996, s. 1077; Shahbazi, 1986, s. 405-406: http://www.iranicaonline.org/articles/ariaeus-military-commander-in-the-army-ofcyrus-the-younger). Genel kanı bu şekildedir. Nitekim Diodoros onu "bir satrap" olarak nitelendirmektedir (Diod. 14.80.8). Polyainus da onun Tissaphernes ve Tithraustes ile eşit itibara sahip olduğundan bahsetmektedir (Polyain. strat. VII.16). Ancak bir başka kaynakta Ariaius, Tithraustes'in astı olarak gösterilmektedir. Hornblower de çeşitli kanıtlar sunarak onun Büyük Phrygia satrapı değil bölgeye gönderilmiş bir yönetim görevlisi olduğunu ileri sürmektedir (Hornblower, 1994, s. 78-79. Hell. Oxy. 19. 3). Tithraustes ise daha sonra Suriye satrapı Abrokomas ve Daskyleion satrapı Pharnabazos ile birlikte Misır'ın yeniden Pers 
hakimiyetine alınması için yapılan başarısız operasyonda (MÖ. 389-87) karşımıza çıkmaktadır (Isok. Paneg. 139-141; Hornblower, 1994, s. 80; Dandamayev, 1983, s. 247: http://www.iranicaonline.org/articles/abrocomas-persian-satrap-of-syria-and-commanderunder-artaxerxes-ii.)

Tithraustes'un görevi meselesi de tıpkı Ariaios’ta olduğu gibi tartışmalıdır. Her şeyden önce Tithraustes, MÖ. 395'teki olaylar üzerine Büyük Kral II. Artakserkses'in Aşağı Asya'ya görevlendirdiği kişidir (Ksen. Hell. III.4.25; Plut. Ages. 10.6-8; Diod. 14.80.7). Tithraustes, Anadolu'ya gönderilmeden önce Pers teşkilatında son derece önemli bir görev olan hazarapati idi (Högemann, 2002, s. 627; Olmstead, 1948, s. 384). Bu unvanın kraldan sonraki en önemli rütbe sahibi olduğu bilinmektedir (Corn. Nep. Kon. III.2-3, Them. 27.2-7; Plut. Alex. 39.9; Briant, 2002, s. 222; Sekunda, 1992, s. 11). Diodoros, kralın onun için Tissaphernes'i tutuklamak için gönderilen komutan olduğunu ( $\dot{\eta} \gamma \varepsilon \mu o ́ v \alpha)$ ve kralın, bütün şehirlere ve satraplara o ne emrederse yapmaları gerektiğine dair mektuplar yolladığını bildirmektedir (Diod. 14.80.7). Yani satrapların hegemonu olarak görevlendirilmiştir (Sekunda, 2011, s. 54). Ancak bu dönemde bölgedeki satrap atamaları daha önceki normal satrap atamaları şeklinde değildir. Satraplık görevinden ziyade bölgenin koruyucusu veya bakıcısı olarak görevlendirmeler yapılmıştır. Hornblower'a göre Tithraustes bu statüde bir yöneticidir. Olağan üstü güçlerle donatılmıştır ve bölgeyi koordine etmekle görevlidir (Hornblower, 1994, s. 77). A. Kuhrt da Pers komuta ve hiyerarşisindeki statüsü belli olmayan Tithraustes'in özel kritik bir durumla ilgili olabileceğini düşünmektedir.(Kuhrt, 2007: 374. n. 2). ${ }^{6}$ Olmstead onu "genç Tithraustes"; Sekunda "II. Tithtaustes" olarak tanımlamaktadır. Sekunda'ya göre bu kişi Kserkses'in gayrımeşru oğlunun büyük oğludur (Olmstead, 1948, s. 428; Sekunda, 2011, s. 55) ve bir mülk (khora) sahibinden çok daha önemli bir görevi olmalıdır. Eğer Büyük Phrygia satrapı olarak atanmadıysa o zaman khorası Kelainai yakınlarındadır (Sekunda, 2011, s. 54-55). Nitekim kaynaklarda Tithraustes'in Büyük Phrygia'nın başkenti olan Kelainai'de olduğundan bahsedilmektedir (Polyain. strat. VII.16.1; Sekunda, 1991, s. 112). Ariaios isyanının bastırılmasında etkin olan Pasiphernes (Hell. Oxy. 19.14.3) de Tithraustes'in “dük”lerinden, yani yerli toprak sahiplerinden biri olabilir (Sekunda, 2011, s. 56). ${ }^{7}$ Benzer durum Ariaios için de geçerli olabilir. Kaynaklarda Kolossai'de ikamet ettiği anlaşılan Ariaios hakkında (Polyain. strat. VII.16.1; Diod. 14.80. 8) araştırmacılar onun da astı olan toprak sahiplerinin bulunduğunu, Tithraustes ile Ariaios'un feodal bir ilişkiye sahip olduğunu düşünmektedir (Sekunda, 2011, s. 56; Olmstead, 1948, s. 384).

II. Artakserkses bir bakıma sorunların üstesinden gelmeyi başarmış gibi görünmektedir. Ancak MÖ. 367/366-359/358 y1lları arasında Anadolu'da tekrar istikrarsız bir ortam oluştu ve Persleri uzun süre uğraştıracak olan satrap isyanları patlak verdi. Zamanla Perslere karşı yapılan kalkışma genişlemeye başladı. Bu istikrarsız durumun ilki Daskyleion ve Lydia arasında, daha sonra Daskyleion satraplığında vuku buldu. Bu dönemde Küçük Asya'da çıkan satrap isyanlarına Lydia satrabı Autophradates, Karialı Mausollos ile Ionia satrabı Orontes ile Hellespontos Phrygia'sı satrabı Ariobarzanes katılmıştı. Bunların haricinde Lykialılar, Pisidialılar, Pamphylialılar, Kilikialılar, Syrialılar, Fenikeliler ve hemen hemen bütün kıyı halkları isyan hareketine dahil oldu (Diod. XV.90.1-4; Corn. Nep. Dat. XIV; Pomp. Trog. prolog. X; Weiskopf, 1989, s. 94; Briant, 2002, s. 656). Persler bu isyanı Orontes'i yanlarına çekerek ancak bastırabildi (Diod. XV. 91. 1-7; Briant, 2002, s. 662-663; isyanlar hakkında detaylı bilgi bkz. Weiskopf, 1989). Burada dikkat çeken husus, isyana katılan söz konusu bölgelerin Büyük Phrygia'yı çepeçevre sarmasına rağmen Büyük

\footnotetext{
${ }^{6}$ A. Kuhrt (2007: 784, 2007a: 1020), Tithraustes'in Persepolis mühürlerinde (PFS) geçen Zishshawish'in Yunanca formu "(Zishshawish (Cicavahush=Tithaens? ; Tithraustes)" olabileceğini ileri sürmektedir.

${ }^{7}$ Sekunda burada Pasiphernes'in Büyük Kral tarafından Aşağı Asya’ya gönderilen bir memur olabileceğini de düşünmektedir.
} 
Phrygia'nın veya buradaki yöneticilerin/görevlilerin bu isyanda isminin geçmemesidir. Nitekim II. Artakserkses'in ölümü üzerine oğulları arasında çıkan taht kavgaları sırasında çıkan isyanların (Sarıkaya, 2015, s. 326-32) Büyük Phrygia'ya da etki ettiği düşünülebilir. İsyan edenlerden biri de Daskyleion satrap1 II. Artabazos idi. Artabazos kral (III. Artakserkses) yanlısı satraplarla çetin bir mücadeleye girişti. MÖ. 356/5'te Atinalı Khares, satrap Artabazos'a yardım etti ve Büyük Phrygia topraklarına kadar saldırı girişiminde bulundu. Kaynaklarda bu sirada bir başka Tithraustes'ten bahsedilmektedir. Buna göre Khares, Tithraustes'in khorasinı ve etrafinı tahrip etti (FGrH 105. F4.25; Diod. 16.22.1-2; Olmstead, 1948, s. 428; Sekunda, 2011, s. 53). Burada bahsedilen Tithraustes ile 390'lardaki Tithraustes ile aynı kişi değildir. Hornblower onun Büyük Phrygia'da değil Hellespontos Phrygia'sında yerleşik olduğunu ancak satrap olmadığını düşünmektedir (Hornblower, 1994, s. 78). Sekunda bu kişiyi III. Tithraustes olarak nitelendirmektedir ve MÖ. 390'lardaki Tithraustes'in büyük oğlu olduğunu iddia etmektedir (Sekunda, 2011, s. 55). Sekunda onun khorasının Kelainai'de (Sekunda, 2011, s. 53), Miller ise Granikos Nehri'nin kaynaklarında uzandığını ifade etmektedir (Miller, 2004, s. 93). Tithraustes khorasının Phrygia'nın batı sınırlarına kadar uzandığı düşünülürse Khares'in Sardeis ve Lydia'dan doğuya doğru bir saldırı düzenlediği söylenebilir. Saldırının ekseni Kolossai ve Kelainai boyunca uzanan yol sistemi üzerinden icra edilmiş olmalıdır (Sekunda, 2011, s. 53). İsyan sonucunda II. Artabazos istediğini elde edemedi. II. Artabazos, Khares'in Atina'ya çağrılması üzerine Thebaialılardan aldığ 1 destekle Pers askerlerini bozguna uğrattıysa da Thebaialı Pammenes'in de çeşitli nedenlerle geri dönmesi üzerine çareyi Makedonya'ya kaçmakta buldu. Böylece MÖ. yak. 478'lerden beri Artabazos'un mensubu olduğu Pharnakes hanedanlığı tarafindan yönetilen Hellespontos Phrygia's1 (Daskyleion) satraplığ bu ailenin ellerinden alınarak başka bir hanedanliktan olan Arsites'e verildi. (Arr. anab. I.12.8-10; Diod. 17.19.4; Paus. I.29.10; Sarıkaya, 2015, s. 326-327, 343).

Pers hakimiyetinin sonlarına doğruysa Büyük Phrygia'nın Büyük İskender'in eline geçtiğini görmekteyiz. İskender'in Asya'ya geçmesi ile birlikte satraplar kendi aralarında bir savaş konseyi toplamış, İskender'e karşı yapılacak olan savaşta Pers komutanlarından Memnon'un bir meydan savaşından kaçınılması gerektiğine dair yaptığı tüm çabalar diğer satraplarca kabul görmemiş, başta Daskyleion satrapı Arsites kendi satraplığındaki evlerin yakılıp yıkılamayacağını ifade etmiş ve neticede savaş kararı verilmişti. Kaynaklar Granikos Savaşı'nda (MÖ. 334) Büyük İskender'in usta manevraları ile Pers kuvvetlerini yenilgiye uğrattığından bahsetmektedir (Arr. anab. I.12.9-10; Plut. Alex. 16; Diod. XVII.18-20; Iust. 11.6.8-13) Körpe ve Yavuz, Granikos'ta Memnon'un geri çekilme önerisine karşı çıkan Arsites'in savaşma düşüncesini, satraplıkların "pek çok Pers malikanesi-arazisi ile dolu" olmasıyla açıklamaktadır. Nitekim Granikos'ta Pers ordusunun önemli bir kısmı kendi arazilerini savunmak için Hellespontos Phrygia'sından gelen İranlılardan oluşmaktaydı (Körpe-Yavuz, 2012, s. 36). Arrianos, Granikos'taki mağlubiyetten sorumlu tutulduğu için Arsites'in Büyük Phrygia'daki Kelainai'ye gelerek intihar ettiğini söylemektedir (Arr. anab. I.16.3). Bu galibiyetten sonra ilk olarak Sardeis'e doğru yola çıkan Büyük İskender, komutanlarından Parmenion'u Daskyleion satraplığını teslim alması için görevlendirdi. Arsites'in bölgesine de satrap olarak Kalas'1 atadı (Arr. anab. I.17.1-10; Curt. III. 1. 24). İskender bundan sonra batı ve güney Anadolu kıyıları üzerinden hareket ederek Lydia üzerinden Karia, Lykia, Pamphylia'ya ulaştı, Pisidia içlerinden kuzeye doğru ilerleyerek Sagalassos (Burdur, Ağlasun) kentinin önünde savunma oluşturan Sagalassosluları kendine has taktikleriyle mağlup etti. Pisidia'daki kalelerin bir kısmını zorla bir kısmını da teslim olmaları yoluyla ele geçiren İskender, daha sonra Askania Gölü (Burdur Gölü) yakınından Büyük Phrygia'daki Kelainai'ye doğru yürüyüşüne devam etti (Curt. III.1.1; Arr. anab. I.1829; Bosworth, 2005, s. 77). Pers hakimiyetinin sonlarına doğru Büyük Phrygia satraplığının başında Atizyes (Atizues) adında bir satrapın bulunduğunu görmekteyiz. 
İskender MÖ. 333'ün kış mevsiminde Büyük Phrygia kenti olan Kelainai'ye ulaştı (Arr. anab. I.29.1). Burada her yanı kayalıklarla çevrili bir kale bulunmaktaydı (Arr. anab. I.29.1; Ksen. anab. I.2.9; Liv. XXXVIII.13.6). Burayı bizzat Büyük Phrygia satrap1 Atizyes savunmaktayd1 (Arr. anab. I. 25. 3-10; I. 29. 1; Diod. 17.21.3; Bosworth, 2001, s. 50). Kelainai'de bin kadar Karialı ve yaklaşık yüz kişilik paralı Hellen savaşçılarından oluşan orduyla mücadele eden İskender, on günlük bir mücadelenin ardından bir anlaşma yaparak şehri ele geçirdi. Anlaşmaya göre eğer altmış gün içerisinde bölgeye destek kuvveti gelmezse şehir teslim olacaktı (Arr. anab. I.29.1-2; Curt. III.1.8). İskender burada zaman kaybetmemek için anlaşmayı kabul etti. Ardından bölgede bir garnizon kurdu. Antigonos'u Büyük Phrygia satrapı olarak atayan İskender, onu, bin beş yüz asker ile bölge güvenliğini sağlaması için Kelainai'de bıraktı. Daha sonra kıș mevsimi içerisinde Gordion'a hareket etti (Arr. anab. I.29.3; Curt. III.1.1-12; Briant, 2002, s. 706). Kralının ölümüne kadar Antigonos burayı elinde tuttu (Bosworth, 2001, s. 52). Büyük Phrygia satrap1 Atizyes ise geriye kalan askerleriyle birlikte III. Darius'a katıldı ve Issos Savaşı'nda hayatını kaybetti (Arr. anab. II.11.8; Briant, 2002, s. 705). İskender'in Büyük Phrygia topraklarında Kelainai'den Gordion'a yürüyüşü sırasında herhangi bir olay olduğuna dair elimizde bir kanıt bulunmamaktadır. Onun Kelainai'den Gordion'a yürüyüşü en az bir ay sürmüş olmalıdır (Bosworth, 2001, s. 52). Böylece daha önce Anadolu'nun kıyılarını ele geçirerek ilerleyen İskender, Büyük Phrygia topraklarına da hakim olarak Anadolu'nun iç bölgelerindeki (özellikle Kelainai’de) Pers nüfuzunu da kırmayı başardı. Neticede Büyük Phrygia'da Pers hakimiyeti sona ermiş oldu.

\section{Büyük Phrygia'daki Şehirler ve Yol Ağları}

Pers döneminde Anadolu'da iki ana güzergâh bulunmaktaydı. Ana yollardan birincisi Kral Yolu olarak bilinen Sardeis-Susa hattı; diğeri özellikle Yunan ve Romalıların kullandığı Güney Yolu hattıdır (Ramsay, 1961, s. 27). Bu iki yolu Tuz Gölü birbirinden ayırmaktadır. Yollardan ilki gölün kuzeyinden geçerken diğeri güneyinden uzanmaktadır (Demir, 2018, s. 29).

Herodotos Kral Yolu'nun korunakl1, güvenilir bölgelerden ve yerleşim alanlarından geçtiğini belirtmektedir (Hdt. V.35). Bu yol ana hatlarıyla Lydia (Sardeis)-PhrygiaKappadokia-Kilikia-Armenia-Kissia-Susa hattı şeklindedir. Buna göre Lydia ve komşusu Phrygia toprakları üzerinde yirmi stathmetikos (konaklama merkezi) bulunmaktadır. Bunların toplam uzunluğu doksan dört buçuk parasang (yaklaşık $520 \mathrm{~km}$ ) etmektedir. Burayı geçtikten sonra Phrygia sınırındaki Halys'e ulaşılmakta ve burayı aşmak için hakim durumda bulunan bir kaleyi geçmek gerekmektedir (Hdt. V.52-54). ${ }^{8}$ Herodotos bu pasajında Kral Yolu'nun geçtiği bölgeleri ve bir takım sayısal veriler sunmaktadır. Ancak kent isimlerinden bahsetmemektedir. Bu durum Kral Yolu'nun geçtiği şehirleri ve güzergahların belirlenmesini zorlaştırmaktadır.

Herodotos bir başka pasajında Kserkses'in Yunanistan seferi hakkında bilgi verirken Pers ordusunun geçtiği şehirleri ve dolayısıyla yol güzergahlarını anlatmaktadır. Onun anlatımına göre Pers ordusu Kappadokia'daki Kritalla'da toplanmış ve buradan hareketle Sardeis'e doğru yola çıkmıştı. Halys'i geçerek Menderes Nehri'nin kaynağının bulunduğu Phrygia'daki Kelainai'ye (Dinar) varan ordu (Hdt. VII.26), Phryg kenti Anaua'nın (Dazkırı, Sarıkavak köyü: bkz. Umar, 1993, s. 67 (Strabon'daki XII.8.13'deki Sanaos); French 1998, s. 17) ve tuz çıkarılan bir gölün (Çardak, Acı Göl: bkz. French, 1998, s. 17) yanından yine bir Phrygia kenti olan Kolossai'ye (Denizli, Honaz) geldi. Ardından Phrygia-Lydia sınırını belirleyen Kydrara'ya (Strabon'da Karura, Denizli-Hieroppolis ? veya Sarayköy yakınları, bkz. aşağıda) ulaştı (Hdt. VII.30). Maiandros'u aşarak Kallatebos (Denizli Buldan'ın komşu

\footnotetext{
${ }^{8}$ Kızılırmak'ın köprü yardımıyla aşılan ve Pteria’ya (Boğazköy) giden güzergahı Büyük Kyros ve Kroisos da kullanmıştı (Hdt. I.73-79).
} 
şehri ? bkz. French, 1998, s. 17) kentine varan Kserkses ertesi gün Lydia'nın başkenti Sardeis'e girdi (Hdt. VII. 7.26-31). Görünüşe göre Kserkses, Herodotos'un tanımladığı yolu, tersine yani batıya doğru gitmişti. Kserkses'in Akhaimenid yönetimi tarafından oluşturulan resmi güzergahı kullandığı düşünülmektedir. D. French, Herodotos'ta geçen iki pasajın aynı rotay1, yani Kral Yolu'nu ifade ettiğini ileri sürmektedir (French, 1998, s. 15-43).

Phrygia bölgesinden geçen yollar hakkında bir başka kaynak Ksenophon'un Anabasis'idir. Herodotos'a nazaran Büyük Phrygia boyunca uzanan şehirler ve konaklardan daha detaylı bilgiler sunan Ksenophon, ayrıca Genç Kyros'un hangi şehirlerde ne kadar kaldığını ve bu şehirlerde neler yaptığını da bildirmektedir. Ona göre Büyük Phrygia şehirleri ve şehirler arasındaki mesafeler şu şekildedir:

Kolassai'den Kelainai'ye 20 parasang, 3 stathmos

Kelainai'den Peltai'ye 10 parasang, 2 stathmos

Peltai'den Keramon-Agora'ya 12 parasang, 2 stathmos

K. Agora'dan Kaystru-Pedion'a 30 parasang, 3 stathmos

K. Pedion'dan Thymbrion'a 10 parasang, 2 stathmos

Thymbrion'dan Tyriaieon'a 10 parasang, 2 stathmos

Tyriaieon'dan Ikonion'a 20 parasang, 3 stathmos (Ksen. anab. I.2.6-19).

Bahsedilen bu güzergah 112 parasangdır ve güzergahta 17 durak noktası bulunmaktadır. Ksenophon'un ifadelerine göre Genç Kyros Kolossai'de ${ }^{9} 7$ gün geçirdi. Thessalialı Menon bin kişilik ağır piyade ve beş yüz hafif piyade ile Genç Kyros'un ordusuna katılmak için buraya geldi. Genç Kyros daha sonra Kelainai'ye hareket etti. Ksenophon, Kelainai' de kalenin alt tarafında Büyük Kralın (Kserkses) müstahkem bir sarayı olduğunu, bu sarayı ve Kelainai kalesini Kserkses'in Hellas'tan geri çekilirken yaptırdığını söylemektedir. Ksenophon, Kelainai'de ayrıca Genç Kyros'un da bir sarayı olduğunu bildirmektedir. Genç Kyros burada otuz gün kaldı (Ksen. anab. I.2.5-9) Lakedaimonialı Klearkhos iki bin kişilik birlikle, Syrakusaili Sosis üç yüz piyadeyle, Arkadialı Sophainetos bin piyade ile Kelainai'ye gelerek Genç Kyros ile buluştu. Kyros'un burada -diğer birliklerini hesaba katarsak- on üç bin piyadesi olduğu ifade edilmektedir. Peltai'de 3 gün geçirdi. Burada Lykaia şenliklerini takip etti. Kilikya kralının karısı Epyaksa ile buluştuğu Kaystrou Pedion'da 5 gün kaldı. Tyriaieon'da 3 gün kaldı. Burada askerlerine resmi geçit yaptırdı. Kilikya kraliçesi ile K. Pedion'dan buraya kadar beraber geldi. Ikonion' da 3 gün kald1. K. Agora ve Thymbrion'da kaldığına dair ise ifade yoktur (Ksen. anab. I.2.6-19). ${ }^{10} \mathrm{Bu}$ dönemde Phrygia'nın Mysia yönündeki son şehri K. Agora; doğudaki son şehri Ikonion'dur (Ksen. anab. I.2.10, 19). Lydia ile Phrygia arasındaki sınır şehri ise Kydrara (Karura, Sarayköy’ün doğusu ? bkz. French, 1998, s. 17) olmalıdır (Hdt. VII.30). W. M. Ramsay, bu yolu güney yolu ya da Pisidia yolu olarak tanımlamaktadır. Ona göre bu yol Kelainai'den Kilikya kapılarına uzanan en kısa yoldur. Bu yol hem su hem gida açısından zengindir (Ramsay, 1920, s. 91-92).

Ksenophon'un haricinde Kelainai'nin tahkimli yapısına Curtius (III.1.6) ve Plutarkhos da işaret etmektedir. Plutarkhos (Eum. VIII.5) Kelainai kırsalında ev ve kalelerin bulunduğunu ifade etmektedir. Sekunda (1991, s. 121-122) kırsaldaki bu kale ve evlerin Tithraustes ailesinin alt statüsündeki Persli toprak sahiplerine ait olabileceğini düşünmektedir. Bunlar için "düka"lığın altındaki şövalyeler ifadesini kullanmaktadır.

\footnotetext{
${ }^{9}$ N. Sekunda (1991: 113) Aphrodisias kentinin Kolossai’nin sınırlarına girdiğini ileri sürmektedir.

${ }^{10}$ Genç Kyros'un Kral Yolundan çıkarak kuzeybatıdaki Peltai’ye yönelmesinin nedeni, karşı tarafi aldatma, yaptığg hareketi gizleme gibi taktiksel bir durum veya maddi sıkıntılar olabilir. Bkz. French 1998, s. 16, 20.
} 
Ksenophon, geçtiği şehirleri özelliklerine göre de kategorize etmiştir. Buna göre Büyük Phrygia şehirlerinden Peltai, Keramon Agora (Uşak civarı), Kaystru Pedion (BolvadinÇay arasındaki ova), Thymbrion (Akşehir Ulupınar ?), Tyriaieon (Ilgın) yoğun nüfuslu şehirler olarak anılmaktadır. Kolossai ve Kelainai şehirleri ise dikkat çekici bir şekilde hem yoğun nüfuslu hem de zengin ve büyük şehirler kategorisine girmektedir. Antik kaynaklar Kelainai şehrinde büyük bir paradeisos (cennet bahçesi) olduğundan, şehirden geçen Marsyas Nehri'nin bölgeyi güzelleştirdiğinden bahsetmektedir (Ksen. anab. I.2.8; Curt. III.1.2-5). Ksenophon'a göre paradeisos, bütün güzelliklerin toplandığı yeryüzündeki en güzel ağaçların bulunduğu yerlerdir. Pers kralları zamanlarının çoğunu burada geçirir ve her nereye gitse bu kraliyet bahçelerinde konaklardı (Ksen. anab. I.2.8; Kuhrt, 2007, s. 510). Krallar burada ayrıca av etkinlikleri de düzenlemekteydi. Bu tarz av partileri aristokratik sınıftan insanların ve gençlerin askeri antrenmanları ve sosyalleşmeleri için de önemli bir faaliyet idi (Strab. XV. 3.18).

Anlaşılan Kelainai, Büyük Phrygia'daki en büyük şehirdi ve Akhaimenid döneminde Büyük Phrygia satraplı̆̆ının başkentiydi (Hell. Oxyrh. 12.3; Liv. XXXVIII.13.4; Briant, 2002, s. 705). Kelainai ve Kolossai şehirleri Büyük Phrygia için olduğu kadar Anadolu'nun da önemli askeri güzergah noktalarındandı. Nitekim kent, Ephesos ve Kuzey Suriye'yi birbirine bağlayan Güney Anadolu yol güzergahının çok önemli bir noktasında yer almaktaydı (Kuhrt, 2007a, s. 294). Dolayısıyla Kelainai şehri hem ordular için gida ve teçhizat malzemesi temin edilebilecek bir yer, hem de toplanma ve harekete geçme mevki (Ksen. anab. I.2.9; Briant, 2002, s. 377) olması sebebiyle Pers dönemi Anadolu'sundaki en mühim şehirler arasında sayılabilir. Bölgenin Persler için stratejik önemini Büyük İskender de kavramış olacak ki Asya seferi sırasında Pisidia üzerinden Büyük Phrygia'ya ilerleyerek Kelainai'de bir garnizon kurma gereği duymuştur (Curt. III.1; Kuhrt, 2007a, s. 294). ${ }^{11}$

Strabon'da da Büyük Phrygia bölgesindeki şehirler ve yollar hakkında bilgiler bulmak mümkündür. Strabon, Ephesus'tan doğuya giden herkesin kullandığı bir rotadan bahsetmektedir. Bu yol Karura (Kydrara, Sarayköy), Laodikeia (Eskihisar), Apameia (Kelainai), Metropolis (Çölovası Tatarlı?) ve Khelidoniae (Karaadilli'nin kuzeyi, Çamurovası) boyunca Sultandağlarının ayaklarında yer alan Holmi'ye (Karamık ovası? Çay) uzanmakta, buradan Philomelium (Akşehir), Tyriaieon (Lagenia, Ilgın) ve Lykonia'ya (Ladik) varmaktadır. Daha sonra Kappadokia sınırına doğru Laodikeia Katakekaumene üzerinden Kappadokia'ya girerek Fırat'a doğru ilerlemektedir (Strab. XIV. 2.29; modern yer adları için bkz. French, 1998, s. 21). D. French, Herodotos, Ksenophon ve Strabon'un vermiş olduğu rotaların birbiriyle bağdaştırılabileceğini düşünmektedir (French, 1998, s. 20). Ancak Ksenophon'da bahsedilen fakat Herodotos'ta bahsedilmeyen üç şehir vardır. Bunlar Peltai (Çivril), Keramon Agora (Susuz), Kaystru Pedion'dur. Bu şehirlerin günümüz DinarAfyonkarahisar (Çölovası-Çay yolu) arasında olduğu düşünülmektedir (French, 1998, s. 16). French bu üç şehrin Dinar'ın kuzeydoğusuna doğru uzanan (modern Çay yolu) yol olup olmadığı konusunda kararsızdır. Ksenophon'un, Keramon Agora'nın Mysia yönündeki son şehir olduğu ifadesinden yola çıkan French bir başka rota daha öne sürmektedir. Bu yol Kelainai'den Eumene'ye (Uşak Çivril yakınlarındaki Işıklı), Sebaste'ye (Selçikler), oradan Banaz Çayı vadisiyle Sincanlı (şimdi Sinanpaşa) ve Afyon'a ulaşmaktadır (French, 1998, s.

\footnotetext{
${ }^{11}$ Kentin önemi Orta çağlarda da devam etmiştir. Nitekim önemli askeri ve ticari yol güzergahı KolossaiKelainai (Apameia) yol güzergahı üzerindeydi. Ortaçă̆ Anadolu'sunun en önemli hadiselerinden olan Myriokephalon Savaşı ve Haçlı Seferleri esnasında Bizans İmparatorları Ioannes Komnenos ve Manuel Komnenos tarafından defaatle düzenlenen Anadolu seferlerinde de bu yollar kullanılmıştı. Kelainai/Apameia şehri Pers döneminde olduğu gibi ortaçağlarda da orduların konakladığı, iaşe ve ibadelerini karşıladığı aynı zamanda Bizans temalarından gelen asker ve malzeme yardımlarının da ordulara katıldığı önemli bir stratejik nokta idi. Bkz. Khoniates, Historia, VI.231; Kinnamos, Historia, II.59.9; Arundell, 2016, s. 107-145; Karaca ve Karacan, 2018, s. 32; Demir, 2018, s. 97-180.
} 
20). Ramsay ise Kral Yolu'nun Kelainai'den geçmediğini ifade eder. Ona göre Kral Yolu doğrudan Uşak üzerinden Keramon Agora'ya oradan ya Amorion üzerinden ya da modern Altıntaş ovasından Nakoleia (Seyitgazi), Pessinus (Ballıhisar) hattından Gordion'a uzanmaktaydı (Ramsay, 1961, s. 29-31; Demir, 2018, s. 31).

Kelainai'den Gordion'a uzanan şehirler ve yollar hakkında Alkibiades'in seyahatini de ekleyebiliriz. Alkibiades'in Kelainai, Synnada, Pyrmnessos üzerinden Kral Yolu'na çıktığ düşünülmektedir. Bu yolun Dokymeion (İscehisar), Klaneos (Bayat), Amorion (Emirdağ), Pessinus (Ballıhisar) şehirlerini takip ederek Gordion'a gittiği düşünülmektedir (Berk, 2011, s. 106).

Bunların dışında konu hakkında bilgi sahibi olabileceğimiz bir başka kaynak Büyük İskender'in Asya seferlerini anlatan eserlerdir. İskender'in Pers seferi sırasında Anadolu'da yürüyüşünü anlatan Arrianos'tan anlaşıldığına göre İskender, daha önce kullanılan Sardeis, Menderes ve Lydia-Phrygia sınırı olan Kydrara rotasından değil; Pisidia (Sagalassos) üzerinden Phrygia topraklarına girmişti (Arr. anab. I. 26-28). İlk uğradığı şehir öncekilerle ortaktır: Kelainai. Arrianos burada muazzam bir kalenin varlığından bahsetmektedir (Arr. anab. I. 29. 1; ayrıca bkz. Curt. III. 1. 6-8). Bu kale daha önce Ksenophon'un bahsettiği kale olmalıdır (Ksen. anab. I.2.8). Curtius da İskender'i Lykia ve Pamphylia üzerinden Büyük Phrygia'ya getirmektedir ve Büyük Phrygia'da ilk kez Kelainai'de karşımıza çıkarmaktadır (Curt. III. 1. 2). Curtius her ne kadar Pisidia ve Sagalassos şehrinden bahsetmese de Pamphylia üzerinden kuzeye giden rotanın Pisidia üzerinden Kelainai’ye geçeceği aşikardır. İskender'in Büyük Phrygia topraklarına giden rotası bakımından Arrianos ile Curtius uyuşmaktadır. Fakat her iki eser de Büyük İskender'in Kelainai-Gordion arasında gittiği güzergah hakkında detaylı malumat vermemektedir. G. Mutlu, İskender'in Kelainai'den Metropolis (Çöl Ovası, Tatarl1), Holmi, Polybotos (Bolvadin) Üçhüyükler, Abasiom (Gömü), Orkistos (Alikel) yolu üzerinden Gordion'a ulaştığını (Mutlu, 2015, s. 44); Berk, Kelainai'den sonra Synnada (Şuhut) üzerinden Yukarı Sangarios ovasına, oradan da Gordion'a uzandığı bildirmektedir (Berk, 2011, s. 103).

Her ne kadar Gordion şehri Hellespontos Phrygia'sı satraplık sınırlarında olsa da şehrin Büyük Phrygia ile olan bağlantısı nedeniyle burada anılmaya değerdir. Coğrafi olarak Gordion şehri Halys kapıları (Avanos'un k.doğusundaki Bozca?) -Phrygia-Kappadokia sinırında stratejik bir noktada bulunmaktaydı (French, 1998, s. 15, 17; Young, 1963, s. 348). Halys de Phrygia-Kappadokia sınırını çizmekteydi (Hdt. V.52.). Anlaşıldığına göre eski Phrygia krallığı toprakları Akhaimenid döneminde de önemli pozisyonunu muhafaza etmiştir. Zira Gordion kenti bir khorion (kale) idi. Bir tepeye inşa edilmişti ve iyi tahkimliydi (Briant, 2002, s. 705). Arkeoloji, nümizmatik ve ikonografik kanıtlar da Perslerin Gordion'daki varlığına ve Gordion'un etrafının Kral Yolu ile çevrelendiğine işaret etmektedir (Briant, 2002, s. 706). Yapılan araştırmalarda Gordion'dan Ankyra'ya giden bir yol bulunmuştur. Bu yolun Pers güzergâhının bir parçası olduğu düşünülmektedir. Sardeis’ten Hermos Vadisi (Gediz) boyunca Leonton Kephalai vasitasiyla Gordion'a giden yol, Ankyra ve Anadolu platosunun ötesine giden Yunan elçilerinin, seyyahların ve orduların yoluydu (Graf, 1994, s. 177; Hdt. V.52. Sardeis-Anadolu platosu arasındaki bahsi geçen yolculuklarla ilgili örnekler için Ksen. Hell. I.4.1; Diod. XIV.11; Plut. Them. 30.1, Alk. 37-39). Nitekim İskender de Gordion'u bir toplanma merkezi olarak belirlemişti ve MÖ. 333 yılı bahar ayı geldiğinde güneyden İskender ile birlikte gelen ve Kelainai'de konaklayan Makedon orduları Gordion'a hareket ederek burada Sardeis'ten süvari ve nakliye kollarıyla gelen Parmenion'un ordusuyla birleşmişti. Bundan başka yeni evli oldukları için önceden Makedonya'ya gönderilenler de Gordion'da toplanmıştı. Ayrıca Atinalı elçiler Granikos'ta esir alınan Atinalıların serbest bırakılmasına dair görüşme yapmak için Gordion'a gelmişti (Arr. anab. I.29.3-5). Daha önce de Gordion önemli bir konaklama merkeziydi. MÖ. 407'de Daskyleion satrabı Pharnabazos, Atinalı 
elçileri Büyük Kralın huzuruna götürürken burada konaklamıştı (Ksen. Hell. I.4.1-2; Briant, 2002, s. 368). Buradan hareketle uzun yıllar Phrygia Krallı̆̆ı'nın başkenti olan Gordion'un Pers döneminde de önemini devam ettirdiğini, Büyük Phrygia bölgesinden hareket edenlerin Gordion'a yöneldiğini, dolayısıyla önemli bir geçiş noktasında bulunduğundan stratejik açıdan dikkate değer olduğunu ifade edebiliriz.

Antik metinlerde geçen Sardeis-Menderes-Kolossai-Kelainai hattının dışında arkeolojik, epigrafik ve nümizmatik kaynaklar -her ne kadar yetersiz de olsa- Uşak-AfyonGordion hattında Pers yerleşimleri olduğunu ve dolayısıyla bu yerleşimler ile bağlantılı yollar bulunduğunu göstermektedir. Bu konuda N. Sekunda, Uşak yakınlarından başlayarak Gordion'a uzanan Pers yerleşimlerini tespit etmeye çalışmaktadır. Ona göre Temenouthyra (Uşak yakınları), İkiztepe (Uşak'ın batısı), Sebaste (Selçikler), Keramon Agora, Leonton Kephalai (İscehisaar? Bkz. Sekunda, 1991, s, 130; Gazligöl, bkz. Drew-Bear, 2000, s, 961), Nakoleia (Seyitgazi), Dareion (Pers yerleşiminden ziyade askeri koloni olabilir), Pessinus, Dindymus Dağı (Murat Dağı) civarında Akhaimenid yerleşimleri olabileceğini ifade etmektedir (Sekunda, 1991, s. 128-138). Yine Sekunda Büyük Phrygia'daki Pers yerleșimleri olduğunu düşündüğü şehirlerden, Phrygia-Lykia sınırında Karia'nın güneydoğusunda Tabai şehrinden (?) (Sekunda, 1991, s. 118); Ptolemaios'un (Geog. V.2.26) bahsettiği Kelainai yakınlarındaki Pisidia sınırında olan Ganzaena/Gazena'dan ${ }^{12}$ ve Alabanda'dan (Blaunda veya ?Pharnakion, Lydia sınırında bir yer? ) bahsetmektedir (Sekunda, 1991, s. 123, 126-128). Herodotos'un Kral Yolu güvenli ve yerleşim olan yerlerden geçmektedir ifadelerine dayanarak, söz konusu şehirlerin doğrudan Kral Yolu'nda olmasa da onunla bağlantılı yolların üzerinde olduğunu söyleyebiliriz.

Şüphesiz kullanılan bu yollar -yeni şehirler ve güzergahlar eklenerek- Pers döneminden sonra da kullanıldı. Dolayısıyla Hellenistik ve Roma dönemlerinde kullanılan güzergahlar bize, Pers döneminde kullanılan güzergahların sağlamasını yapması bakımından yardımcı olmaktadır. M. Vulso, Galat seferinde Apamea (Kelainai), Metropolis (Tatarl1), Dyniae (Çamurovası, Karaadilli), Synnada (Şuhut) yolundan ilerlemişti (Livius XXXVIII.1215). Romalı Cicero, Cato'ya yazdığı mektubunda (MS.51) Kilikia'ya gitmek ve orduya katılmak için gittiği güzergahtan bahsetmektedir. Buna göre Cicero Laodikia, Apamea, Synnada, Philomelium, Lykonia, Ikonium üzerinden Kilikia'ya ulaşmıştı (Arrundel, 2016, s. 125). Buradan anlaşılacağ dönemde karşımıza çıkan yerler büyük oranda paralellik göstermektedir.

Elbette ki burada bahsettiğimiz yollar kraliyet yolları ile ilgilidir. Yunan yazarlar bunu $\dot{\alpha} \mu \alpha \xi ı$ ı́ $\varsigma$, (hamaxitos=tekerlekli arabalara layık) olarak adlandırmıştır. Hamaxitos ifadesi Susa-Persepolis, Susa-Arbela, Susa-Hyrkania yolları için kullanıldığı gibi Phrygia-Kilikia yolu için de kullanılmıştır. Sadece askerler değil aynı zamanda seyyahlar, siviller, $\alpha \rho \mu \alpha ́ \mu \alpha \xi \alpha$ (harmamaxa, otağ arabaları) tarafından da kullanılan bu yolların bütün hatlarının taş döşeli olduğu düşünülmemelidir (Briant, 2002, s. 360-361). Çeşitli genişlikte olan bu yollar kumlu ve çakıllı, fakat iyi muhafaza edilmiş ve belirgindi (Ksen. anab. I.5-7-8). Kraliyet yollarının haricinde daha kısa olan, genellikle bir dağ ya da çöl geçitlerini takip eden ara yolların olduğunu da belirtmeliyiz (Briant, 2002, s. 360). Mesela Sardeis'ten Karia satraplik merkezine giden bir yol olmalıdır ki bu yol büyük ihtimalle Hdt. V.52'deki Sardeis-Ephesus Kral Yoluna bağlanmaktaydı. Kuzeybatı Anadolu'da Kyzikus, Propontis'in güney kıyıları ve Lampsakus üzerinden batıya uzanan eski bir Pers yolu daha olmalıdır (Graf, 1994, s. 177). Aynı şekilde Büyük İskender'in takip ettiği Fahliyun-Pers kapıları ile Hyrkania yolu; Kambyses'in Mısır seferinde kullandığı çöl güzergahı; Polydamas'ın Ekbatana'ya (Hemedan)

\footnotetext{
${ }^{12}$ Sekunda bu ismin eski Farsça'da "hazine” için kullanılan Ganza- kelimesi ile ilişkilendirilebileceğini buradaki Gazena şehrinin de Büyük Phrygia’daki bir hazinenin bulunduğu yer olduğunu düşünmektedir.
} 
gittiği Tuz Çölü geçiş yolu bu tarz yollardandır (Briant, 2002, s. 360). Buradan hareketle Büyük ihtimalle Anadolu güzergahındaki Büyük Phrygia bölgesinden geçen her iki ana yol hattı da bu tarz yan ve ara yollar ile birbirine bağlanıyor olmalıdır.

\section{Sonuç}

Büyük Kyros'un yayılmacı politikası neticesinde ele geçirilen bölgeler yönetim bölgelerine ayrılmıştır. Bu yönetim bölgelerinden biri de Phrygia'dır. Pers döneminde Anadolu'da iki ayrı Phrygia bölgesi mevcuttur. Biri Hellespontos Phrygia'sı, diğeri Büyük Phrygia. Büyük Phrygia bölgesine de tıpkı Hellespontos Phrygia'sında olduğu gibi hanedan üyelerinin veya soylu İranlıların yönetici tayin edildiği, bölgede birçok Pers khorasının ve asil Pers yerleşiminin bulunduğu, buraların tahkimatlarla güçlendirildiği dikkat çekmektedir.

Erken dönemlerde Büyük Phrygia ile ilgili bilgiler yeterince zengin değildir. Bölgenin ne zaman satraplık olarak ayrıldığı bilinmemektedir. Ancak MÖ. 4. yüzyılda yaşanan meselelerden anlaşıldığına göre MÖ. 4. yüzyılda ayrı bir yönetim bölgesi olduğu düşünülebilir. Özellikle Genç Kyros meselesinden sonra Anadolu'da meydana gelen başkaldırı olayları, Büyük Krala sadık bir bölge oluşturmak için atılmış bir adımın neticesinde yeni bir bölge oluşturulmuş olabilir. Nitekim Anadolu'nun batı (kıyı) ve iç batı bölgeleri daima Perslerin otoritesini zayıflatacak olayların adresi olmuştur. Bu bölgelere daima Hellen müdahalesi söz konusudur. MÖ. 500/499 yılında ortaya çıkan İyon isyanı ile başlayan bu durum özellikle MÖ. 5. yüzyılın sonlarındaki Genç Kyros'un darbe planında, MÖ. 4. yüzyılın başlarındaki Sparta (Agesilaos) - Pers mücadelelerinde ve aynı yüzyılın ortalarına doğru patlayan büyük satrap isyanlarında ve Atinalı Khares meselesinde net bir şekilde karşımıza çıkmaktadır. Özellikle sayıca çok fazla olmayan, Pers topraklarında olduğu için erzak, silah vs. tedariki konusunda sıkıntı yaşaması muhtemel olan bir Agesilaos komutasındaki bir ordunun Anadolu'nun batı kıyıları bir yana iç bölgelere doğru girebilmesi söz konusu bölgelerdeki Pers merkezi otoritesinin zaafiyetine yorumlanabilir. Ancak MÖ. 4. yüzyılda yaşanan Persler açısından sıkıntılı olaylara Büyük Phrygia açısından baktığımızda, bölgenin etrafinı saran diğer satraplıklara nazaran dış müdahaleye daha sert ve krallığa sadık davranıldığını düşünmekteyiz. Özellikle (II.)Tithraustes'in (ayrıca Rhathanes'in) MÖ. 4. yüzyıldaki tavrı bu açıdan dikkate değerdir.

Coğrafi konumu nedeniyle Phrygia kentleri Anadolu'daki ulaşım ağlarının merkez noktasındadır. Büyük Phrygia'nın sınırları güneyde, batıda ve kuzey batıda Pisidia (Pamphylia-Lykonia ?)-Lydia-Mysia hattından doğuda Ikonion'a uzanmaktadır. Söz konusu sınırlar içerisinde birçok yerleşim yeri bulunmakla beraber en önemli kentlerin Kelainai ve Kolossai şehirleri olduğunu söyleyebiliriz. Gordion şehri Hellespontos Phrygia'sı sınırlarında olmasına rağmen Büyük Phrygia ile olan bağlantısı nedeniyle Gordion'u da bu bağlamda anabiliriz. Bu şehirlerin Pers dönemi Anadolu'sundaki yol güzergahları dikkate alındığında stratejik noktalarda konumlandığını görebiliriz. Bu bağlamda Gordion-Ankyra-Pteria hattı Anadolu'daki önemli bir geçiş bağlantısıdır. Bu hattı batıya bağlayan anahtar şehir ise Kelainai'dir. Kelainai şehrinin eskiçağ kaynaklarında -ayrıca ortaçağlarda- doğu-batı doğrultusunda Büyük Phrygia'nın en önemli şehri, Anadolu'nun da en mühim şehirlerinden biri olduğu anlaşılmaktadır. Ksenophon'un burayı büyük, zengin ve yoğun nüfuslu olarak göstermesi; sarayların ve büyük bir paradeisosun bulunduğunu ifade etmesi; Kserkses, Genç Kyros, Büyük İskender ve Diadokhlar tarafından merkezi bir konum olarak kullanılması Kelainai'yi Akhaimenid hakimiyeti döneminde Anadolu'daki diğer şehirlerden farklı kılmıştır. Tüm bunlardan hareketle Kelainai, Kolossai ve Gordion şehirlerinin doğu-batı doğrultulu yapılacak büyük seferler veya yolculuklar için stratejik öneme haiz merkezler olduğunu, söz konusu kentlerin sahip oldukları niteliklerden dolayı sosyal açıdan da gelişmiş 
olduklarını düşünebiliriz. Son olarak Kral Yolu ile Güney Anadolu yol hattının kuzey-güney doğrultulu yan yollar ile muhtemelen birbiriyle bağlantılı olduğunu söyleyebiliriz.

Arr. $a n a b . \quad$ (= Arrianus, Anabasis)

\section{Antik Kaynaklar ve Kısaltma Cetveli}

Kullanılan Metin ve Çeviriler: Anabasis Alexandri. English Translation by E. Iliff, B.D. Robson, Vol. I, Books I-IV. London-Cambridge, Massachusetts, Harvard üniversity press, 1967; Aleksandrou Anabasis, Çev. Furkan Akderin, İstanbul, 2005.

Corn. Nep. (=Cornelius Nepos)

Ages. $\quad$ (=Agesilaos)

Dat. $\quad$ (=Datames)

Kon. $\quad$ (=Konon)

Kullanılan Metin ve Çeviri: Ünlü Komutanların Yaşamları. Çev. Furkan Akderin, İzmir, 2011. On Great Generals. On Historians. Translated by J. C. Rolfe. Cambridge, MA: Harvard University Press, 1929 (LOEB).

Curt. (=Quintus Curtius Rufus, Historiae Alexandri Magni)

Kullanılan Metin ve Çeviri: History of Alexander. Çev. John C. Rolfe, 1946 (LOEB).

Ctes. (=Ctesias)

Kullanılan Metin ve Çeviriler: Ctesias's History of Persia. Translation by Lloyd LlewellynJones, James Robson, Routledge Classical Translation, London, New York, 2010.

DB. (= Darius I, Behistun Inscription)

Kullanılan Metin ve Çeviri: Tolman, H.C., Ancient Persian Lexicon and The Text of The Achaemenidian Inscriptions Transliterated..., American Book Campany, New York, vd. 1908; Kent, R.G., Old Persian Grammar, Texts, Lexicon, American Oriental Society, New Haven, Connecticut, 1950; Kent, R.G., The Nakš-İ Rustam Inscriptions of Darius, Language, $15 \quad$ (3), 1939, $\quad$ s. 160-177; http://www.livius.org/sources/content/achaemenid-royal-inscriptions/ (Erişim Tarihi: 12.07.2019)

DPe. (=Darius I, Persepolis)

Kullanılan Metin ve Çeviri: Kent, R.G., Old Persian Grammar, Texts, Lexicon, American Oriental Society, New Haven, Connecticut, 1950.

DSe. (=Darius I, Susa)

Kullanılan Metin ve Çeviri: Kent, R.G., Old Persian Grammar, Texts, Lexicon, American Oriental Society, New Haven, Connecticut, 1950.

Diod. (= Diodorus Siculus, Bibliotheke Historike)

Kullanılan Metin ve Çeviri: Diodorus Siculus, Diodorus of Sicily in Twelve Volumes, English Translation by C. H. Oldfather. Vol. 4-8. Harvard University Press, London, Cambridge, Mass., 1989 (LOEB).

FGrHist (=Die Fragmente der griechischen Historiker)

Kullanılan Metin: Felix Jacoby, Zewiter Teil Zeitgeschichte, C, kommenter zu NR 64-105, Berlin, Leiden, New York, Köln, 1993.

Hell. Oxy. (= Hellenica Oxyrhynchia)

Kullanılan Metin ve Çeviriler: Hellenica Oxyrhynchia. Paul McKechnie and S.J. Kern (ed), Warminster, Aris and Phillips, 1988.

Hdt. $\quad$ (= Herodotos, Historiae)

Kullanılan Metin ve Çeviriler: The Histories, English Translation by A. D. Godley, Harvard University Press, Cambridge 1920; Histories. Çev. Müntekim Ökmen, İstanbul 2009.

Isok. Paneg. (=Isokrates, Panegyricus)

Kullanılan Metin ve Çeviri: Panegyricus. With an English Translation by George Norlin, in three volumes, I, London, New York, 1928. 
Iust. (=Marcus Junianus Iustinus, M. Iuliani Iustini Epitoma Historiarum Philippicarum Pompei Trogi)

Kullanılan Metin ve Çeviri: Epitome of the Philippic History of Pompeius Trogus, Trans: John Selby Watson, London, 1853.

Khoniates (=Niketas Khoniates, Historia)

Kullanılan Metin ve Çeviriler: Historia, Çev. Fikret Işıltan, Türk Tarih Kurumu Yayınları, Ankara 1995.

Kinnamos (=Ioannes Kinnamos, Historia)

Kullanılan Metin ve Çeviriler: Historia, Çev. Işın Demirkent, Türk Tarih Kurumu Yayınları, Ankara, 2001.

Ksen. Ages. (=Ksenophon, Agesilaos)

Kullanılan Metin ve Çeviri: Xenophon in Seven Volumes, E. C. Marchant, G. W. Bowersock, tr. Constitution of the Athenians, Harvard University Press, Cambridge, MA, London, 1925.

Ksen. anab. (= Ksenophon, Anabasis)

Kullanılan Metin ve Çeviriler: Anabasis, Book I-III, English Translation by C. L. Brownson, London, New York 1921; Anabasis. Book IV-VII, English Translation by C. L. Brownson, Harvard University Press, London, Cambridge, Mass. 1947 (LOEB); Anabasis (onbinlerin dönüşü), Çev. Oğuz Yarlıgaş, İstanbul 2011.

Ksen. Hell. $\quad$ (= Ksenophon, Hellenika)

Kullanılan Metin ve Çeviriler: Hellenica, Books I-V, English Translation by C. L. Brownson, Cambridge, Mass., London, Harvard University Press, 1961 (LOEB); Yunan Tarihi, IIII, Çev. Suat Sinanoğlu, Milli Eğitim Bakanlığı, nd.

Ksen. Kyr. (= Ksenophon, Kyropaedia)

Kullanılan Metin ve Çeviriler: Cyropaedia, English translation by Walter Miller, London, New York 1914; Kyros'un ĕgitimi, Çev. F. Akderin, İstanbul 2007.

Liv. (=Ab Urbe Condita)

Kullanılan Metin ve Çeviriler: Livy, The History of Rome, Books XXXVIII-XXXIX, English Translation by Evan T. Sage, Harvard University Press, Cambridge, Mass., London, 1936 (LOEB).

Paus. (= Pausanias, Periegesis tes Hellados)

Kullanılan Metin ve Çeviri: Description of Greece. With an English translation by W. H. S. Jones, Books I and II, London, New York 1918 (LOEB).

Plut. (=Plutharkhos, Bioi Paralelloi)

Ages. (=Agesilaos)

Artaks. (=Artakserkses)

Arist. (=Aristeides)

Alex. (=Aleksandros)

Eum. (=Eumenes)

Kim. (=Kimon)

Them. (=Themistokles)

Alk. (=Alkibiates)

Kullanılan Metin ve Çeviri: an English Translation by B. Perrin, London, Cambridge, Mass., Harvard University Press, Vol. II 1914, IV 1916, V 1917, VII 1919, VIII 1919, XI 1954 (LOEB).

Pomp. Trog. prolog. (= Pompeius Trogus, Prologues)

Kullanılan Metin ve Çeviri: Epitome of The Philippic History of Pompeius Trogus, Translated by J. C. Yardley, With Introduction and Explanatory Notes by R. Develin, Oxford University Press, 1994.

Strab. (= Strabon, Geographika) 
Kullanılan Metin ve Çeviriler: The Geography of Strabo VII, Book 15-16, Translated by Horace Leonard Jones, London, New York, 1917 (LOEB); Coğrafya, Çev. A. Pekman, İstanbul 2000.

Thuk. (= Thukydides)

Kullanılan Metin ve Çeviri: Peloponnessos savaşı, Çev. T. Gökçöl, İstanbul 1976.

\section{Kaynakça}

Arrundell, F.J.V. (2016). Küçük Asya'da keşifler. (D. Dereli, Çev.). İstanbul: Arkeoloji ve Sanat Yayınları.

Barkworth, P. (1993). The organization of Xerxes army. Iranica Antiqua, 27, 149-167.

Bosworth, A. B. (2001). Conquest and empire: the reign of Alexander the Great. Cambridge University Press.

Bosworth, A.B. (2005). Büyük İskender'in yaşamı ve fetihleri: Fetih ve imparatorluk. (H. Çalışkan, Çev.). Ankara.

Briant, P., (1999). The Achaemenid empire. K. Raaflaub, N. Rosenstein, (Ed.). War And Society in Ancient And Medieval World. Washington.

Briant, P. (2002). From Cyrus to Alexander: A history of the Persian empire. Winona Lake, Indiana, Eisenburg.

Calder, W.M. (1925). The royal road in Herodotus. The Classical Review, 39, 7-11.

Casabonne, O. (2007). Akhamenid imparatorluğu büyük kral ve Persler. Arkeoatlas, 6, 20-35.

Cline, E. H. (2018). MÖ. 1177 medeniyetin çöktüğ̈̈ yıl. (A. Kuglin, Çev.). İstanbul: Bilge Kültür-Sanat Yayınları.

Dandamayev M. (1983). Abrocomas. Encyclopcedia Iranica, 1/3, 247. online edition: http://www.iranicaonline.org/articles/abrocomas-persian-satrap-of-syria-andcommander-under-artaxerxes-ii (Erişim Tarihi: 28.08.2019)

Demir, F. (2018). Ortaçă̆ Anadolu'sunda Denizli ile Konya arasındaki yol güzergahları (12. yüzyıl). Yayımlanmamış Yüksek Lisans Tezi. Süleyman Demirel Üniversitesi Sosyal Bilimler Enstitüsü, Isparta.

Drew-Bear, T. (2000). Map 62 Phrygia. R. J. A. Talbert (Ed.), Barrington Atlas of the Greek and Roman World (Volume 2), Princeton University Pressss.

Drews, R. (2012). Tunç çă̆ının sonu. (T. Ersoy, G. Ergin, Çev.). İstanbul: Türkiye İş Bankası Kültür Yayınları.

French, D. (1998). Pre and early Roman road of Asia Minor: the Persian royal road. Iran, 36, 15-43.

Graf, D. (1994). Persian royal road system. H. S.-Weerdenburg, A. Kuhrt, M. C. Root (Ed.), Achaemenid History, VIII, Leiden, 167-189.

Herzfeld, E. (1968). The Persian empire. Weisbaden.

Hornblower, S. (1994). Persia. D. M. Lewis, J. Boardman, S. Hornblower, M. Ostwald (Ed.), Cambridge Ancient History VI: The Fourth Century (Second Edition), Cambridge: Cambridge University Press.

Högemann, P. (2002). Tithraustes. H. Cancik, H. Schneider (Ed.); Der Neue Pauly, 12/1, 627.

İren, K. ve Yıldızhan, H. (2017). Pers Daskyleionu: Güney Marmara bölgesi'nde bir satraplık merkezi. K. İren, Ç. Karaöz, Ö. Kasar (Ed.), Persler Anadolu'da Kudret ve Görkem, ss. 332-345: İstanbul: Yap1 Kredi Yayınları.

Jacobs, B. (2006). Achaemenid satrapies. Encyclopcedia Iranica. (Online edition 2011). http://www.iranicaonline.org/articles/achaemenid-satrapies Published: August 15, 2006). (Erişim Tarihi: 01.09.2019)

Karaca, B. ve Karacan, K. (2018). Frederic Barbarossa'nın haçlı seferi ile Miryokefalon savaş güzergâhı ilişkisi ve Miryokefalon savaş yeri Tzipritze. Süleyman Demirel Üniversitesi Sosyal Bilimler Enstitüsü Dergisi, 32, Isparta, 241-264. 
Kaya, M.A. (2018). Anadolu'da Pers satraplıkları: Kuruluş, yönetim ve etnik yapı. CEDRUS. VI, 159-179.

Kuhrt, A. (2007). The Persian empire: A corpus of sources from the Achaemenid period (Volume 2). London, New York.

Kuhrt, A. (2007a). The Persian empire: A corpus of sources from the Achaemenid period (Volume 2). London, New York.

Kuhrt, A. ve Sancisi-Weerdenburg, H. (1996). Ariaeus. H. Cancik, H. Schneider (ed.), Der Neue Pauly, 1, 1077.

Maffre, F. (2007). Kıyı Phrygiası ve Troas. Arkeoatlas, 6, 84-89.

Maffre, F. (2017). Pers hakimiyeti altında Anadolu halkları. K. İren, Ç. Karaöz, Ö. Kasar (Ed.), Persler Anadolu'da Kudret ve Görkem, 52-61: İstanbul: Yap1 Kredi Yayınları.

Miller, C. M. (2004). Athens and Persia in the fifth century bc: A study in cultural respectivity. Cambridge University Press.

Muscarella, O. W. (2013). Archaeology, artifacts and antiquites of the ancient near east: Sites, cultures, and proveniences. Leiden, Boston: Brill Published.

Occhipinti, E. (2016). The Hellenica Oxyrhynchia and historiography: new research perspective, Mnemosyne supplements: Monographs on Greek and Latin language and literatüre (Volume 395). Leiden Boston: Brill Published.

Ramsay, W.M. (1920). Military operations on the north front of Mount Taurus. Journal of Hellenic Studies, 40, 89-112.

Ramsay, W.M. (1961). Anadolu'nun tarihi coğrafyası. (M. Pektaş, Çev.). İstanbul.

Sarıkaya, S. (2015). Pers idari sistemi perspektifinde bir satrapllk merkezi Daskyleion. Yayımlanmamış Doktora Tezi. Akdeniz Üniversitesi Sosyal Bilimler Enstitüsü, Antalya 2015.

Sarıkaya, S. (2015a). Agesilaos'un Daskyleion seferleri (M.Ö. 396-395). Phaselis I, 199-219.

Schmitt, R. (1986). Achaemenid dynasty; from the Persian clan of the same name ca. 700 to 330. b.c. Encyclopoedia Iranica, 1, Londra, Costa Mesa, 414-426.

Sekunda, N. (1988). Persian settlement in Hellespontine Phrygia. A. Kuhrt, H. SancisiWeerdenburg (Ed.) Achaemenid History, III, Leiden, 175-195.

Sekunda, N (1992). The Persian army 560-330 bc. London.

Sekunda, N. (1991). Achaemenid settlement in Caria, Lycia and Greater Phrygia. A. Kuhrt, H. Sancisi-Weerdenburg (Ed.), Achaemenid History, VI, Leiden, 83-143.

Sekunda, N. (2011). Changing patterns of land-holding in the south-western border of Greater Phrygia in the Achaemenid and Hellestic periods. A. H. Cadwallader, M. Trainor (Ed.), Colossae in Space and Times: Linking To An Ancient City, Göttingen: Vandenhoeck and Ruprecht.

Sevin, V. (1982). Anadolu'da Pers egemenliği. Anadolu Uygarlıkları 2. İstanbul.

Sümmerer, L. (2010). Duvar resimleri. L. Sümmerer, A. von Kienlin (Ed.) Tatarlı Renklerin Dönüşü, 120-185: İstanbul: Yap1 Kredi Yayınları.

Umar, B. (1993). Türkiye'deki tarihsel adlar, İstanbul: İnk1lap Kitabevi.

Weiskopf M. (1994). Dascylium. Encyclopcedia Iranica (Online edition): www.iranicaonline.org/articles/dascylium (Originally Published: December 15, 1994. This article is available in print.Vol. VII, Fasc. 1, pp. 85-90).

Weiskopf, M. (1989). The so-called great satrap's revolt 366-360 b.c. Wiesbaden, Stuttgart.

Young, R.S. (1963). Gordion on the royal road. Proceedings of The American Philosophical Society, $107 / 4,348-364$. 